\title{
EPICLADIUM SMALL OR GUARIANTHE DRESSLER \& W.E. HIGGINS (ORCHIDACEAE)?
}

\author{
JOHN BECKNER \\ Curator Orchid Identification Center, Marie Selby Botanical Gardens, 811 South Palm Ave., Sarasota, \\ Florida 32667, USA. jbeckner@selby.org
}

\begin{abstract}
Guarianthe Dressler \& W.E.Higgins as a genus has found little favor with orchid growers. If these species are a distinct genus from Cattleya Lindl., under any name, the effects will be substantial. All taxa of this alliance are of considerable horticultural importance, as species and in the ancestry of thousands of garden hybrids. In any case, Guarianthe cannot be replaced by Epicladium Small, which was based on Epidendrum boothianum.
\end{abstract}

RESUMEN. El nombre genérico Guarianthe Dressler \& W.E.Higgins ha sido poco aceptado por los horticultores. Si se trata de un género diferente a Cattleya Lindl., este hecho es significativo. Todas las especies de Guarianthe tienen gran importancia hortícola y han dado origen a miles de híbridos artificiales. En todo caso, Guarianthe no puede ser reemplazado por Epicladium Small, el cual se basa en Epidendrum boothianum. Ambos nombres genéricos no son equivalentes.

Key Words / Palabras Clave: Cattleya, Epicladium, Guarianthe, botanical nomenclature.

Julian Shaw, Royal Horticulture Society Senior Registrar for Orchid Hybrids, has announced (Shaw 2004) that: "Guarianthe Predated by Epicladium. Epicladium (Lindl.) Small is the name with date priority for the generic concept recently described as Guarianthe Dressler \& W.E. Higgins. Therefore hybrid genera involving Guarianthe will not be used in registration. Appropriate nothogenera will be provided in due course". There are several issues raised by this announcement.

Guarianthe (Dressler \& Higgins 2003, Higgins 2004) as a genus has found little favor with orchid growers. If these species are a distinct genus from Cattleya Lindl., under any name, the effects will be substantial. The plants long known as Cattleya bowringiana Veitch and Cattleya aurantiaca (Batem.) Don have been involved in thousands of garden hybrids, many of great popularity. This taxonomic issue about the genera is independent of the name used.

Lindley, in Hooker's Journal of Botany 3: 81. 1841, wrote, "Having lately had occasion to reconsider the large genus Epidendrum, I have been led to attempt its subdivision upon more natural characters than those used in the Genera and Species of Orchidaceous Plants, the result of which is given in the following account of the subgenera I propose to adopt."

Lindley's subdivisions, on page 97 of The Genera and Species of Orchidaceous Plants (1831), have no names, merely numbers, letters, and brief diagnosis. They are groups of species that are rather arbitrary, and there are no types singled out, so they need not influence later nomenclature. Of the species Lindley gives under Epidendrum, only E. bidentatum Lindl. is part of the present issue. It is a later homonym of Epidendrum bidentatum J.König, from Asia. The name Epidendrum boothianum Lindl., and its subsequent generic assignments, refer to Lindley's E. bidentatum and this account will deal with this species below.

Returning to Lindley in 1841, he numbers and names 10 subgenera. No type species are named and there is no list of the contents of each subgenus. Number II is named Epicladium. It is described as "Caulis pseudobulbosus (fusiformis). Flores racemosi, e spatha erumpentes. Labellum liberum." A comparison with the other subgenera suggests that only the spathe distinguishes Epicladium. But the "fusiformis" may suggest that Epidendrum aurantiacum Lindl. (1838b), was what he had in mind. Suggest, but nothing more. In 1838a, he had also published Epidendrum boothianum.

In 1853, Lindley published an enlarged account of Epidendrum, in Folia Orchidacea (p. 1-97). Now there are twelve "Sub-genera," the first of which is Epicladium. Lindley on the preceding page refers to these as "divisions". I assume he just meant "part of", not a taxonomic level. Epicladium includes three species. 
None of the subgenera have type species designated. The three species in Epicladium are E. aurantiacum Batem., E. campylostalix Rchb.f., and E. boothianum Lindl. The ICBN (Greuter et al. 2000), Article 10.5 and Ex. $6 \&$ 7, forbids mechanical choosing of type species, such as the first one listed. Lindley singles out E. aurantiacum in his brief "section" discussion. $\mathrm{He}$ used "subgenus" and "section" interchangeably on the same page (see Articles 35.3, 11.2, 4.1 \& 4.2). "In $E$. aurantiacum, the calli or linear plates so common in the genus are replaced by three raised lines, the ovary has a very long cuniculus, and the flowers have the regularity of the Hexisean Isochiles." These comments could be interpreted as raising doubts about this species belonging in the group, or even the genus. On the other hand, Lindley says "... the pseudo-bulbs are evidently assuming the condition of an ordinary stem". That fits E. aurantiacum, but not the other two species.

On page four, under sub-genus Encyclium, Section A. Holochilum, is Epidendrum aureum Lindl., transferred from Broughtonia aurea Lindl., Bot. Reg. 1840, Misc. 22, from Mexico. He says it is, "apparently perfectly distinct". But subsequent authors have made it a synonym of Cattleya aurantiaca (Epidendrum aurantiacum)! Backing up two pages, it is also interesting to note that Lindley did not mention Cattleya aurantiaca (Lindley) G. Don of 1840, a name published thirteen years before! The Folia never dealt with Cattleya as a genus, and Lindley's dislike of Don perhaps kept the combination excluded.

All this is relevant to the Epicladium vs. Guarianthe generic issue only if "subgenus Epicladium" was transferred to generic status (Article 11.2), and if the type of Epicladium at either level is what is commonly known as Cattleya aurantiaca. The other two species in 1853 are quite different from it and resemble each other in many ways. Withner \& Harding (2004), have put them in separate genera, as Prosthechea boothiana (Lindl.) W.E. Higgins and Pollardia campylostalix (Rchb.f.) Withner. Having seen many plants of each in flower in the wild, I can only comment how similar yet distinct they appeared.

It should also be mentioned that Withner \& Harding (p. 257) illustrate "Prosthechea boothianum" (sic) with a Jane Herbst drawing. The lip is non-resupinate and rolled down along the sides. The pseudobulbs are fusiform! I have never seen such a plant, but assume it is subsp. favoris. Their P1. 85, a Greg Allikas photo, shows the lip resupinate, with rolled sides.
Subgenus Epicladium Lindley was mentioned a few times during the sixty years following Lindley's Folia. Heinrich Gustav Reichenbach (Reichenbach filius 1856) had a repeat of Lindley, followed by a new arrangement based on inflorescence position. Subgenus Epicladium is clearly in his Acranthium, and within Encyclium as a part of it. In 1862 he has Acranthium "sectio Epicladium Lindl.", which includes Lindley's three original species, plus the entirety of Cattleya and also Epidendrum hastatum Lindl. Lindley had not published such a section and Reichenbach filius did not claim it as his own. No type species is indicated.

Pfitzer (1888a) has four sections of Epidendrum, several with subgroups of unstated rank within them. They are nomenclaturally mostly attributed to Lindley, who had not published these as sections or subsections. There is no mention of Epicladium or its three original species under Epidendrum, nor under Cattleya (Pfitzer 1886b).

Bentham \& Hooker (1883) list and discuss sections of Epidendrum. The E. aurantiacum is referred to as Cattleya, but with smaller flowers. E. boothianum is referred to section Encyclia which has three subgroups, but neither Epicladium nor its constituents are explicitly placed. Under Cattleya they mention Reichenbach filius putting Cattleya into "Sectionem Epicladium".

On April 26, 1913, J.K. Small (1913a) published a new genus Epicladium Small, in his Flora of Miami (p. 56). Only one species is listed, E. boothianum (Lindl.) Small. Small did not need to cite full bibliographic information on the species combination in 1913. That went into effect "on or after 1 January 1953" (Article 33.3.). Small's generic account says nothing of transferring Lindley's subgenus, and the description fits the Florida species. Earlier authors had stated that subgenus or section Epicladium had a lip free from the column. Small in his generic key (p. 51) to Orchidaceae and in his generic description refers to the column as partially adnate to the lip. He also defines the genus as having flattened pseudobulbs. These two characters clearly exclude Epidendrum aurantiacum.

Column adnate to about the middle: lip obscurely 3lobed, with a minute middle lobe and broad and short lateral lobes: pseudobulbs flattened: flowering stem subtended by a foliaceous spathe.

There is a strange confusion at the back of the book (p. 200), where new genera and species are listed. 
EnCYCLIA Small. Epidendrum, subgenus Encyclia Lindl.

Encyclia tampensis (Lind.) Small. Epidendrum tampensis Lindl.

Epicladium Boothianum (Lindl.) Small. Epidendrum Boothianum Lindl.

A few weeks later (11 August), Small (1913b) used his genus Epicladium in his Flora of the Florida Keys with only minor changes in text. Twenty years later he repeated his use of the name in his Manual of the Southeastern Flora (p. 366)

Column adnate to about the middle: lip obscurely 3lobed, with a minute middle lobe and broad and short lateral lobes: pseudobulbs flattened: flowering stem subtended by a foliaceous spathe.

and on p. 392 (Small 1933), but modified his key and text:

40. Epicladium Small. Epiphytic herbs with short flattened pseudobulbs which bear several short erect leaves and a relatively short mostly simple flowering stem which is subtended by a long foliaceous spathe. Flowers erect or ascending, subtended by minute bracts. Perianth small, but showy. Lateral sepals rather short, about as wide as the median one. Petals nearly resembling the lateral sepals or more dilated upward. Lip shorter than the sepals and petals, the blade usually rhombic. Column partly adnate to the lip. Capsule nodding, winged. -One species.

1. E. Boothianum (Lindl.) Small. Plant 1-2 dm. tall, with flattened suborbicular pseudobulbs: leaf-blades spatulate, 6-12 cm. Long: flower-stem simple: lateral sepals $11-13 \mathrm{~mm}$. long, elliptic or slightly broadened upward: petals broadly spatulate, brown-spotted like the sepals: lip yellow or mainly so; blade rhombic, 4-6 $\mathrm{mm}$. long, the broad lateral lobes spreading; capsulebody $25-30 \mathrm{~mm}$. long. [Epidendrum Boothianum Lindl.] - Hammocks, S pen. Fla. and the Keys. - (W.I.) - Fall.

Note that Small indicates that his genus is only one species. That is not a reference to only Florida. Small consistently gave his own estimate of the global size of each Spermatophyte genus in his over 1500 page book. See for example Polystachya on the next page: "about 170 species". Thus he was aware of the great diversity of that genus in Africa. Clearly, E. aurantiacum and E. campylostalix were being excluded from the genus
Epicladium by Small. In all three books, Small cited "(Lindl.) Small" as authority for the species, but only "Small" for the genus. We cannot read his mind and do not have his written explanation of the generic name. Possibly, he just liked the word and used it. Even if he intended to transfer it, he did not so explicitly. (Article 46.6 limits us to internal evidence as set forth explicitly.)

After Small, Epicladium faded from use. Acuña (1939, "1938"), followed Small closely in his account of Cuban orchids. But Ames, Hubbard \& Schweinfurth (1937) overwhelmed botanists with their book The Genus Epidendrum in North and Middle America. They all but ignored subgenera and sections, putting pseudobulbous species of diverse vegetative and floral characters into § ENCYCLIUM. Ames, Hubbard and Schweinfurth (p. 6) said: "Of late years the tendency has been to recognize the Lindleyan sections as distinct genera, but our studies lead us to believe that Lindley, with his knowledge of fewer species, recognized sections which merge into one another". On page 7 they cite Epicladium Small as a generic synonym of Epidendrum Linnaeus. On page 9, their "Key to Species and Varieties" begins with:

I. Stems with true pseudobulbs surrounded by scarious non-leaf-bearing sheathes; leaves one or more borne at or near the summit of the pseudobulb; column wholly free from or adnate to the lip (including Aulizeum, Hormidium, Osmophytum and Psilanthemum)

In 1961 Dressler resurrected Encyclia as a genus and within a decade or so, nearly all botanists followed him. In 1998 ("1997”) Higgins carved out Prosthechea. In recent years, Dressler, Higgins, Withner and Harding, Chiron, etc. have offered further changes.

As a taxonomically and nomenclatural irrelevant aside, it is amusing to note that Schultes \& Pease (1963) offered the following etymology of Epicladium Small (p. 128):

Epicladium Small, Fl. Miami (1913), 56.

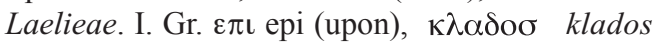
(twig), from its epiphytic habit.

W.T. Stearn (1973: 402), translates "Clad-" as "branch". None of Lindley's three original species is a twig epiphyte, nor can we picture the up to two-meter wide clumps of the species later referred to Guarianthe 
dangling so precariously! Lindley no doubt just meant a plant growing on a tree branch, which is true for all three of his species.

Cassio van den Berg \& Mark W. Chase (2004a) state on page 223 that they include Guarianthe as a genus in the Cattleya alliance (I). Epicladium is not mentioned, but presumably is put by them in the Encyclia Alliance (VII), on the same page.

In addition, van den Berg \& Chase (2004b) on page 228 , for 1913 , refer only to Schlechter's publications of Newcogniauxia and Domingoa. Epicladium Small is therefore omitted.

To summarize:

1) Lindley used a subgeneric name Epicladium in 1841. It had been used a few times since, including misplacement as a section name. It had three species: Epidendrum aurantiacum, E. boothianum, and E. campylostalix. The first is unlike the other two and he expressed some doubts about its placement. He did not give a type.

2) Small in 1913, used a generic name Epicladium for one of Lindley's three species. It was the only one he mentioned and twenty years later he indicated it was the only species in the genus. He did not base his genus explicitly on Lindley's subgenus.

3) A name has priority only at the level where it was published.

4) Guarianthe includes one of Lindley's three species, but not the one picked by Small for his genus. Therefore, Epicladium and Guarianthe are not equivalent. Each may be regarded as a generic synonym, but under different genera in the two cases.

Acknowledgments. Thanks to Dr. Wesley E. Higgins for calling this problem to my attention and urging that it should be published. Thanks also to Heather Hill, Administrative Assistant at Selby for invaluable assistance in preparing this paper. Many thanks also to late Dr. John Kunkel Small, the greatest botanist to work on plants in Florida. His over 100 publications have been a lifelong inspiration.

\section{Literature Cited}

Acuña Gale, J. 1939 (“1938”). Catálogo Descriptivo de las Orquídeas Cubanas. Secretaría de Agricultura, República de Cuba. p. 88-89.

Ames, O., F.T. Hubbard \& C. Schweinfurth. 1936. The Genus Epidendrum in the United States and Middle America. Botanical Museum, Cambridge, Massachusetts. p. 6-8, 66, 100, 122.
Bentham, G. \& J.D. Hooker. 1883. Genera Plantarum. William Pamplin, London. Vol. 3, part 2: 528-532.

Don, P.N. 1840. Cattleya aurantiaca. Florist 's Journ. 185.

Dressler, R.L. 1961. A Reconsideration of Encyclia. Brittonia 13: 253-266.

Dressler, R.L. \& W.E. Higgins. 2003. Guarianthe, a generic name for the "Cattleya" skinneri complex. Lankesteriana 7: 37-38.

Greuter, W., J. McNeill, F.R. Barrie, H.-M. Burdet, V. Demoulin, T.S. Filgueiras, D.H. Nicolson, P.C. Silva, J.E. Skog, P. Trehane, N.J. Turland \& D.L. Hawksworth (eds.). 2000. International Code of Botanical Nomenclature (Saint Louis Code). Koeltz Scientific Books, Germany.

Higgins, W.E. 2004. Guaria Morada by Any Other Name is Still an Orchid. Orch. Digest 68(1): 3739.

Higgins, W.E. 1998 (1997). A Reconsideration of the Genus Prosthechea (Orchidaceae). Phytologia. 82(5): 370-383.

Lindley, J. 1831. The genera and species of orchidaceous plants. London (Ridgways, Piccadilly). p. 97. (July 1831).

Lindley, J. 1838a. Edwards's Botanical Register 24: misc. 5-6.

Lindley, J. 1838b. Edwards's Botanical Register 24: Misc. 8

Lindley, J. 1840. Edwards's Botanical Register misc. 22 p. 19.

Lindley, J. 1841. Notes upon the genus Epidendrum. J. Bot. (Hooker) 3: 81.

Lindley, J. 1852-1855. Folia Orchidacea 1: 1-97. J. Matthews, London.

Pfitzer, E. 1888a. Die Natürlichen Pflanzenfamilien, Orchidaceae 2(6): 144-145.

Pfitzer, E. 1888b. Die Natürlichen Pflanzenfamilien, Orchidaceae 2(6): 146.

Reichenbach f., H.G. 1856 ("1858”). Xenia Orchidacea 1: 134-137.

Reichenbach f., H.G. 1862 ("1874”). Xenia Orchidacea 2: 26-29.

Schultes, R.E. \& A.S. Pease. 1963. Generic Names of Orchids. Academic Press, New York.

Shaw, J.M.H. 2004. Orch. Rev. (Supplement) 112: 76.

Small, J.K. 1913a. Flora of Miami. Small, New York. p. 51.

Small, J.K. 1913b. Flora of the Florida Keys. Small, New York. p. 36-37.

Small, J.K. 1933. Manual of the Southeastern Flora. Small, New York. p. 366, 392.

Stearn, W.T. 1973. Botanical Latin. David \& Charles, Newton Abbot. 
van den Berg, C. \& M.W. Chase. 2004a. A Reappraisal of Laeliinae. Orch. Digest 68(4): 220-226.

van den Berg, C. \& M.W. Chase. 2004b.AChronological View of Laeliinae Taxonomic History. Orch. Digest
68(4): 226-230, 252-254.

Withner, C.L. \& P.A. Harding. 2004. The Cattleyas and their Relatives: The Debatable Epidendrums. Timber Press, Portland. 
